\title{
ECOLOGICAL-ECONOMIC ZONING OF THE CITY OF ALTINÓPOLIS - SP, BRAZIL
}

Doi:http://dx.doi.org/10.1590/1809-4430-Eng.Agric.v36n6p1218-1228/2016

\section{RAFAEL C. CRIVELENTI ${ }^{*}$, CÉLIA R. P. BUENO ${ }^{2}$, JOSÉ S. R. PIRES ${ }^{3}$, JOSÉ FRANCISCO ${ }^{4}$, BRUNO F. LESSI ${ }^{4}$}

\author{
${ }^{1 *}$ Corresponding author. Universidade Estadual Paulista Júlio de Mesquita Filho, Câmpus de Jaboticabal/ Jaboticabal - SP, Brasil. \\ E-mail: rafael@agrobio.agr.br
}

\begin{abstract}
Since colonial times, Brazilian land use has been made under an extractivist model at the expense of deforestation, increasing soil and vegetation depletion, stream siltation, as well as loss of biodiversity. An ecological-economic zoning (EEZ) has been taken as feasible alternative to guide public policies aimed at city land-use planning. This study focused on designing an EZZ for the city of Altinópolis, in São Paulo state (Brazil), by means of geographical information systems (GIS). Information and maps delineated six land-use areas, in which $30 \%$ covered areas under environmental protection, $45 \%$ over areas with groundwater recharge potential, which should be intended to restoration. Furthermore, around $70 \%$ of the territory show potential to be grown with agroforestry systems due to soil, climate and relief conditions. These results point out demand for further public policies to encouraging preservation of existing forests and restoration of degraded areas, mainly those covering groundwater-recharge areas.
\end{abstract}

KEYWORDS: geographical information systems, soil and water preservation, environmental planning, land use.

\section{INTRODUCTION}

Law n ${ }^{\circ}$. 6,938/ 1981 pertains to the National Environment Policy (PNMA) and represents a breakthrough on environmental legislation. In this legislation are established basic concepts about environment, degradation, pollution, setting of goals, guidelines, tools and the liability theory, defining, thus, all systematic of Brazilian policies for the environment (MILARÉ, 2011).

The tools of this law are grounded by the art. \# 225 of the Federal Constitution, at $\S 1$ and its lines, among which it is advised a certain environmental quality standard, evaluation of impacts, environmental zoning and permit (ANTUNES, 2015).

According to the PNMA, environmental zoning (EZ) is a legal instrument of land use planning and diagnosis, bounding zones where certain activities are permitted or forbidden - fully or partially, besides other activities extractivist activities (MACHADO, 2013). Such information shall provide backgrounds for further decisions by the municipal government (SOUZA, 2009).

From Ordinance number 4,297, released in 2002, EZ was henceforth termed Ecologicaleconomic Zoning - EEZ, in which land zoning has incorporated social economic attributes and sustainability to those of environmental protection, conservation and natural resource recovery (SOUZA, 2013).

In Brazil, the first studies were performed in a national scale, mainly within the Amazonia, due to its high deforestation rates during the 80's and the 90's. They aimed at mapping natural and social phenomena, as a background to planning and managing projects focused on farming activities and urban designing for the enrolled states (BRASIL, 2003).

A few tools are used to assist in this zoning diagnosis and definition such as remote sensing and other GISs (NOVO, 2010; KONECNY, 2014).

\footnotetext{
${ }^{2}$ Universidade Estadual Paulista Júlio de Mesquita Filho, Câmpus de Jaboticabal/ Jaboticabal - SP, Brasil.

${ }^{3}$ Universidade Federal de Santa Catarina/ Florianópolis - SC, Brasil.

${ }^{4}$ PPG-Ecologia e Recursos Naturais, Universidade Federal de São Carlos/ São Carlos - SP, Brasil. 
Such systems are vital to EEZ designing, once they enable, through dataset storing, identifying the economic, environmental and social profile of the city under evaluation, by means of maps and reports. Therefore, public and private enterprises may be supported during decisionmaking regarding plans, programs, projects and activities that, directly or indirectly, make use of natural resources (SOUZA, 2009).

It is noteworthy mention that even though it is technique of utmost importance for policies of urban development and sprawl, few has been performed at city scale in further details (ARAUJO et al., 2011). Conversely, there is a demand to direct farming and livestock activities, chiefly near native vegetation areas. In this sense, Altinópolis stands out for lying on a great geomorphological variability. The area has distinct types of soils and large native forest fragments. Besides of that, it is located within a transition between Cerrado (savannah-like vegetation) and the Atlantic Forest (Rain Forest), having its economy based on agriculture.

Thus, this study focused on designing an ecological-economic zoning for Altinópolis - SP (Brazil), using geographical information systems to set areas of interest to environmental protection, recovery, farming, groundwater recharge, special use and urban areas, providing guidelines to the government.

\section{MATERIAL AND METHODS}

\section{Study area}

The area under study is the town of, found in the northern state of São Paulo, Brazil. Compared with the surrounding cities, it stands out by owning large areas of native forest still preserved, besides being laid on remaining vegetation belonging to two distinctive biomes, Cerrado and Atlantic Forest. Lastly, these areas are under no specific law protection as part of conservation units (RODRIGUES \& HOTT, 2010).

Particularly, the area is located within the geographical coordinates of $47^{\circ} 24^{\prime} 06^{\prime \prime}$ to $47^{\circ} 29^{\prime} 08.85^{\prime \prime}$ 'west longitude and $20^{\circ} 48^{\prime} 57.75^{\prime \prime}$ 'to $21^{\circ} 12^{\prime} 23.54^{\prime \prime}$ 'South latitude, central meridian of 45 degrees and occupies nearly $930 \mathrm{~km}^{2}$ in extension (Figure 1). Local climate is classified as highaltitude tropical ( $\mathrm{Cwa}$ ), according to the Köppen's classification. Located on the watershed of the Pardo and Sapucai river basins, the city has a widespread river network. The geological basis consists of sandstones from Botucatu and Pirambóia formations, and basalts from Serra Geral, belonging to the group of São Bento (IPT, 1981).

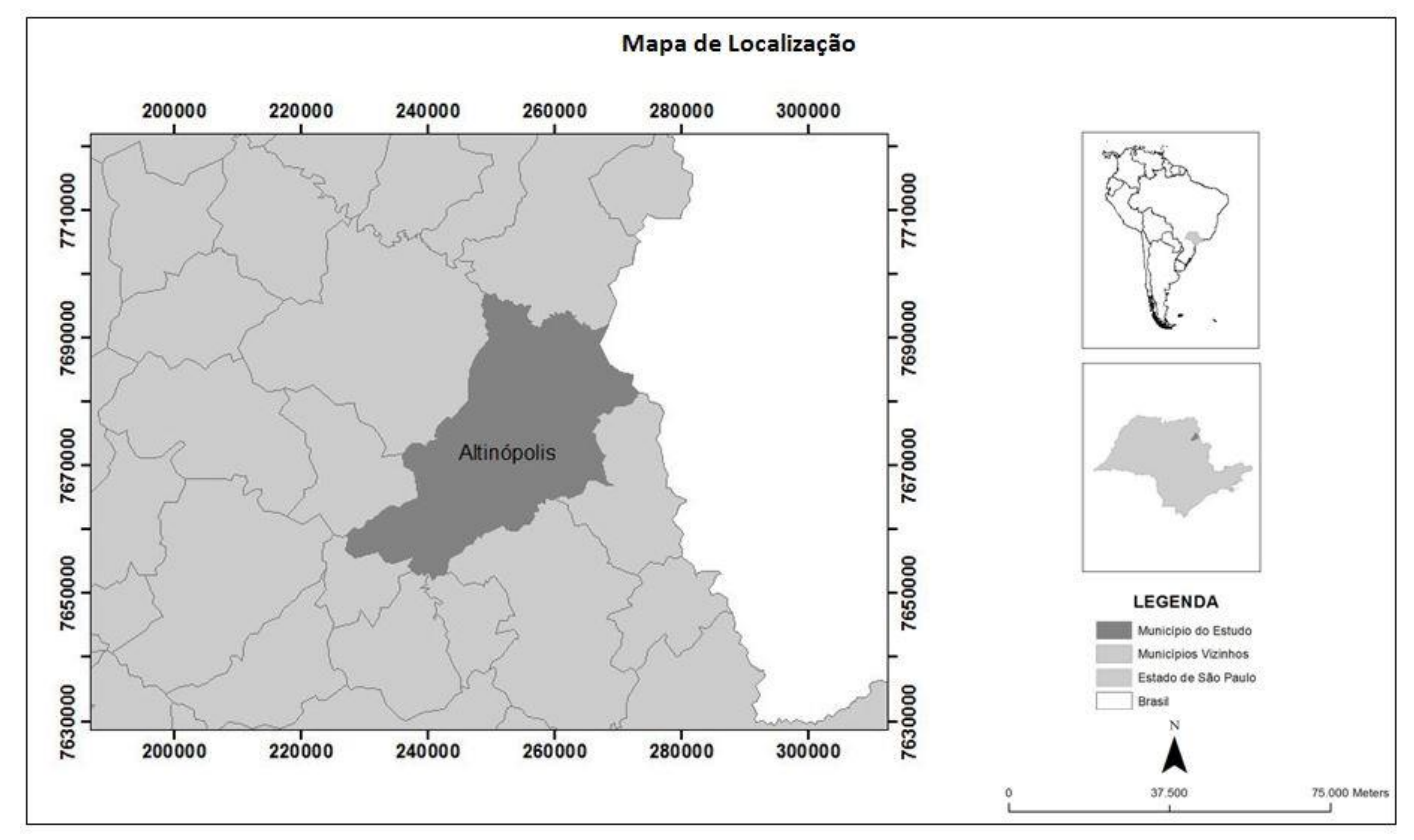

FIGURE 1. Altinópolis position with São Paulo state, and study area delimitation. 
On an average altitude of $900 \mathrm{~m}$, plateaus, plains and extensive wetlands, mainly on basaltic "cuestas" throughout landscape, characterize relief. Soils are characteristic of such environments, with predominance of Red Latosol (Oxisol) covering much of the city, and also Neosols and Gleysols (Entisols) (OLIVEIRA et al., 1983).

Local climate, geomorphology and pedology make farming activities possible, being primary sector the main activity. Sugarcane, eucalyptus, coffee, pasture and grains, among others as rice, potato, onion, beans and fruits (avocado and citrus) stand out locally. So far, land-use guidelines are needed to improve farming without conflicts and further soil, water and biodiversity depletions, once there is a vast native vegetation covering the area.

\section{Database setup}

Land use diagnosis started by vectorizing, through ArcGIS software (ESRI, 2011), the scale 1: 50,000 topographic sheets of the cities of Altinópolis (Sheet SF-23-V-C-II-1), Serrana (Sheet SF23-V-C-I-2), Esmeril (SF-23-V-A-V-3), Itamoji (Sheet SF-23-V-C-II-2) and São Tomás de Aquino (Sheet SF-23-V-A-V-4). The Brazilian Institute of Geography and Statistics (IBGE) (Figure 1) developed these sheets. Among the information in point include: road network, hydrography, hypsography and the boundaries of the city.

Later, thematic geological maps (polygons and lines) of the Agency for Research and Mineral Resources (CPRM) scale 1: 750,000 (PERROTTA et al., 2005), and thematic soil maps of the Agronomic Institute of Campinas, scale 1: 500,000 (OLIVEIRA, 1999) were vectorized and integrated into the map of the city boundaries.

Maps of the farming area and native forest remnants were obtained via photo-interpretation of satellite images (Geoeye), available for the year of 2013. Then, data were compared to data surveyed for LUPA project in 1996, enabling verification of changes in land use along the recent years (TORRES, 2008). After photo-interpretation, field visits were carried out to update the information gathered by satellite.

After geo-referencing data into a single database - GIS environment, processing started using the same com projections (UTM) and datum (SIRGAS 2000). Derived maps, as digital elevation model (DEM), were designed from contours and quoted/ vectorized points on the cartographic base (IBGE topographic sheets). For this, a topo raster was created using a 3D Analyst module of ArcGIS software (ESRI, 2011).

Based on DEM, relief morphometric variables of interest were extracted, e.g. slope map, setting six classes according to erosion susceptibility, which were: plain (0 to $3 \%$ ), gently undulating (3 to 6\%), moderately undulating (6 to 12\%), undulating (12 to $25 \%$ ), strongly undulating ( 25 to $45 \%$ ) and hilly (above 45\%) (RAMALHO FILHO \& BEEK, 1995).

To limit restrictive land use areas, due to environmental protection, the principles of the Forest Code were taken into consideration for permanent protection areas (PPAs), which was made by buffers along watercourses and existing springs, as well as on hillsides and hilltops (OLIVEIRA \& FERNANDES FILHO, 2013). This procedure followed law number 12,651/2012 and ordinance number 8,235/2014, delimiting native forest areas (SODRÉ, 2013).

Once defined, this information was crossed by the clip module of ArcGis with land use information, in which areas under law protection and occupied with crops, highlighting areas of interest for environmental recovery.

The areas of agricultural potential were bordered based on the crossing of soil type and slope maps, withdrawing environmental protection areas. Yet a groundwater recharge map was built from the intersection of soil and geology information, defining thus four recharge priority classes.

Lastly, special use zones were bounded from vectorization of highways, farm lanes, railways and streams (sheets IBGE), scale 1: 50,000, available for the city, as well as urban area and its expansion zone. 


\section{RESULTS AND DISCUSSION}

The geological map shows vast sandstones coverage, coming from the formations Pirambóia $(35.2 \%)$, Botucatu (29.25\%) and Itaqueri (4.85\%). Yet the basalts are from Serra Geral and take up $23.5 \%$ of the entire territory. Linked to that, the soil map highlights Quartzarenic Neosols (53\%) and Red Latosols (30\%), Red-yellow Latosols (8.8\%), as well as other less significant soil classes (Figure 2).

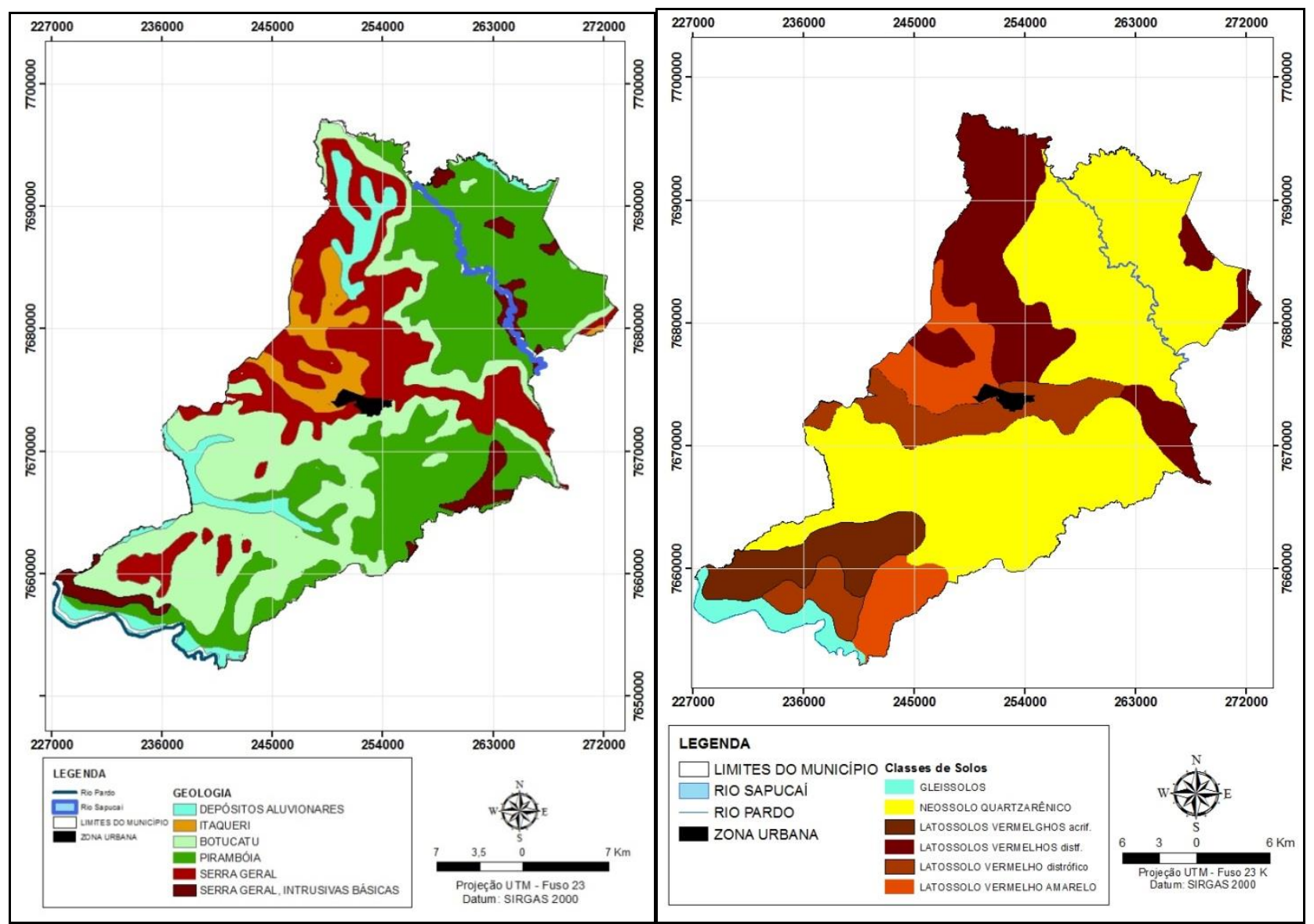

FIGURE 2. Geological and soil maps of the city of Altinópolis - SP, Brazil.

About $45 \%$ of the city area showed certain priority for groundwater recharge; of this, $64.5 \%$ are ordinary, $21.5 \%$ high, $13 \%$ moderate and $1 \%$ low (Figure 3). Raising awareness on this subject is of utmost importance, since, in particular areas of this city, it is seen the upwelling of the Guarani aquifer.

Soil maps, in Figure 3, demonstrate groundwater recharge areas of high, normal and moderate priority are largely covered by native forests, which is good for their protection. Nonetheless, farming areas are significant, of which sugarcane and eucalyptus cover $50 \%$ of high priority protection areas and $70 \%$ of the moderate ones, highlighting further differential management system. 


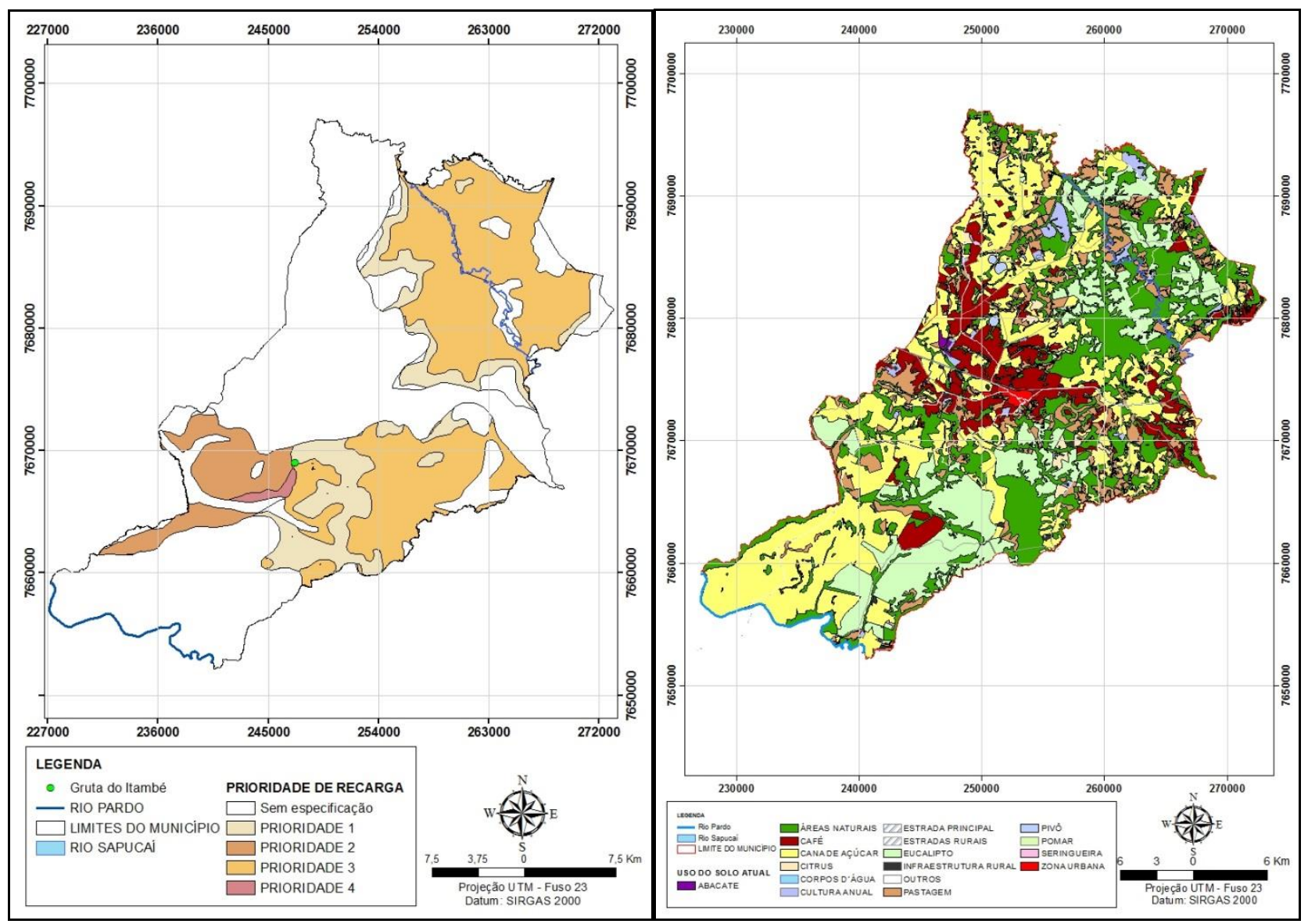

FIGURE 3. Map of priority protection areas for groundwater recharge and land use, Altinópolis - SP, Brazil.

In 1996, pastures (29\%) and native forests covered the city. However, over the years, large sugarcane and eucalyptus industries were set and as coffee plantations, they strengthened due to fertile soils and high altitude, changing thus land use. In 2007, grazing areas were reduced to $14 \%$ of the total area, which nowadays represent only $10 \%$ (Table 1).

TABLE 1. Progress of land use in Altinópolis city during the last 20 years.

\begin{tabular}{lccc}
\hline Land use (\%) & 1996 & 2007 & 2014 \\
\hline Sugarcane & 18.8 & 30 & 32 \\
Eucalyptus & 18 & 17 & 16.2 \\
Coffee & 7 & 8.2 & 8.9 \\
Pasture & 29 & 14 & 10.7 \\
Annual crop & 5.2 & 2.6 & 1.4 \\
Native forest & 14 & 22 & 27.8 \\
Others & 8 & 6.2 & 3 \\
\hline Total & 100 & 100 & 100 \\
\hline
\end{tabular}

Sugarcane has grown over the pasture areas, which currently fill $32 \%$ of the total area, mainly on Pardo river basin, since it is the closest to alcohol and sugar plants. This area is composed by sandy soils, demanding most caution when being cropped. Coffee plantations also increased considerably (25\%), occupying $8.9 \%$ of the territory. Moreover, reductions on areas grown with other year crops as corn and soybeans have decreased, likewise the eucalyptus planted forest.

Despite this great sugarcane raise in recent years, there still has resistance to this crop monoculture. Sugarcane increased more than 50\% in grown area in São Paulo state, for the last 10 years, which was brought mainly due to information and technology, increasing production area and yields for such crop (GOMES \& MONTAÑO, 2012). 
Other researches on EEZ have also shown similar results as the one developed by GARCIA et al. (2010). These authors performed macro zoning of Tambaú city, in São Paulo state, identifying a highly anthropized landscaping, covered predominantly with sugarcane (above 45\%) and few environmentally protected areas (20\%), with forest remnants, besides PPAs that have to be recovered.

It is noteworthy seeing that farmlands lay on flat (0 to $3 \%$ ) to gently undulating (3 to $6 \%$ ) relieves, where clayey Red and Red-yellow Latosols (Oxisols) are expressive, classified as 1 and 2 for agroforestry aptitude. On the other hand, there are areas without farming restriction on moderately undulating (6 to 12\%) and undulating (12 to 25\%) relieves, in both Latosols and Neosols, they are classified as 3. Finally, areas strongly undulated (25 to 45\%) and hilly (over 45\%) have higher constraints, representing respectively classes 4 and 5, regardless soil type (Figure 6), which, however, are mostly occupied by native vegetation (Figure 4).

Additionally, slope map played a key role on EEZ in respect of areas under environmental restriction (steep PPAs and hilltop) and farming potential (Figure 4). It aided in selecting areas fit for mechanization and others under high risk of erosion with restrict use.

Furthermore, we may highlight that the key factors for farming expansion and strengthening in this city are either soil and geology traits or climate and relief, since a $12 \%$ slope covers $60 \%$ of the area.

Conversely, agricultural cultivation has enabled removal of cattle from field and Cerrado areas, contributing to soil conditions and increasing native forest through natural regeneration. Currently, $28 \%$ of the city territory are now covered in forest fragments. This increase in vegetation can also be explained in part by improving spatial resolution of satellites, which enabled detection of new fragments within São Paulo state (ZORZETTO, 2010).

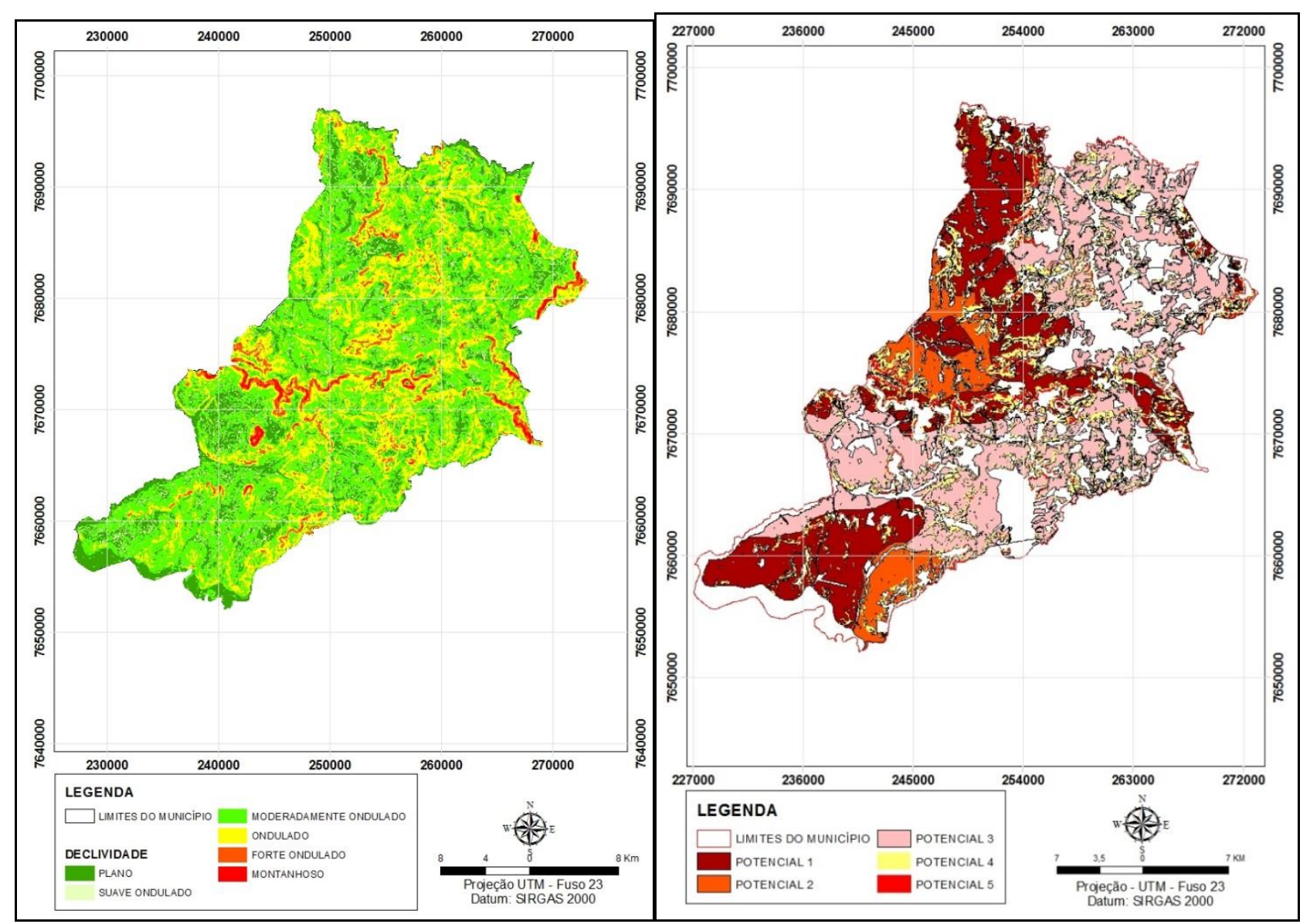

FIGURE 4. Map of slope and zones of interest and agroforestry potential in the city of Altinópolis - SP, Brazil. 
However, an area of 21,651 ha (23\%) are currently forest fragments from transition between Cerrado and Atlantic Rainforest, to which, added all PPA types makes $29.5 \%$ of the total area intended to environmental protection (Figure 6).

These vegetation areas together with the PPAs were marked out as Areas of Interest and Environmental Protection (Figure 5). Based on the analysis of PPAs, we may say that 5,736 out of 93,210 ha, i.e. 6\%, are under such purpose, from which PPAs springs and streams. Areas of slopes above $45^{\circ}$ account for 57 ha, hilltop for 30.2 ha and water damming for 16.8 hectares (Table 2).

TABLE 2. Areas of Interest and Environmental Protection in the city of Altinópolis - SP, Brazil.

\begin{tabular}{lcc}
\hline Permanent Protection Areas (PPAs) & Number & Área (ha ${ }^{1}$ ) \\
\hline Springs & 641 & 500 \\
Streams & 894 & 5,236 \\
Damming (above one hectare) & 17 & 16.8 \\
Slope & Above $45 \%$ & 57 \\
Hilltop & 1 & 30.2 \\
General PPA & - & 5,840 \\
Overlap between PPAs & - & 185 \\
Total PPA & - & 5,665 \\
Conserved PPA & - & 4,320 \\
Degraded PPA & - & 1,335 \\
Native forest fragments & - & 21,651 \\
Total native forest & & 25,971 \\
Areas of interest and environmental protection & - & 27,306 \\
\hline
\end{tabular}

Nevertheless, noteworthy part of these areas are in conflict with applicable law, in 1,335 ha, with anthropogenic action on the borders causing degradation (Figure 5). Nearly 24\% of the PPAs are degrading, being thus considered as Zones of Environmental Recovery (Figure 6); thereby management actions and removal of degrading factors should be carried out. Pastures (50\%) and sugarcane $(29 \%)$ currently occupy these degraded PPAs within the recovery zone (Table 3).

TABLE 3. Land use in the areas of interest for environmental restoration of the city of Altinópolis - SP, Brazil.

\begin{tabular}{lcc}
\hline Land use & Degraded area (ha) & Percentage \\
\hline Sugarcane & 385 & 29 \\
Eucalyptus & 88 & 6.5 \\
Pasture & 668 & 50 \\
Coffee & 112 & 8 \\
Others & 82 & 6.5 \\
TOTAL & 1,335 & 100 \\
\hline
\end{tabular}

Part of these areas stand out as consolidated use, with no need of restoration, since it may had been occupied before the year 2008, as provided for by the article \# 61 of Law 12,651/ 2012; however, restoration activities promote soil and water conservation. 


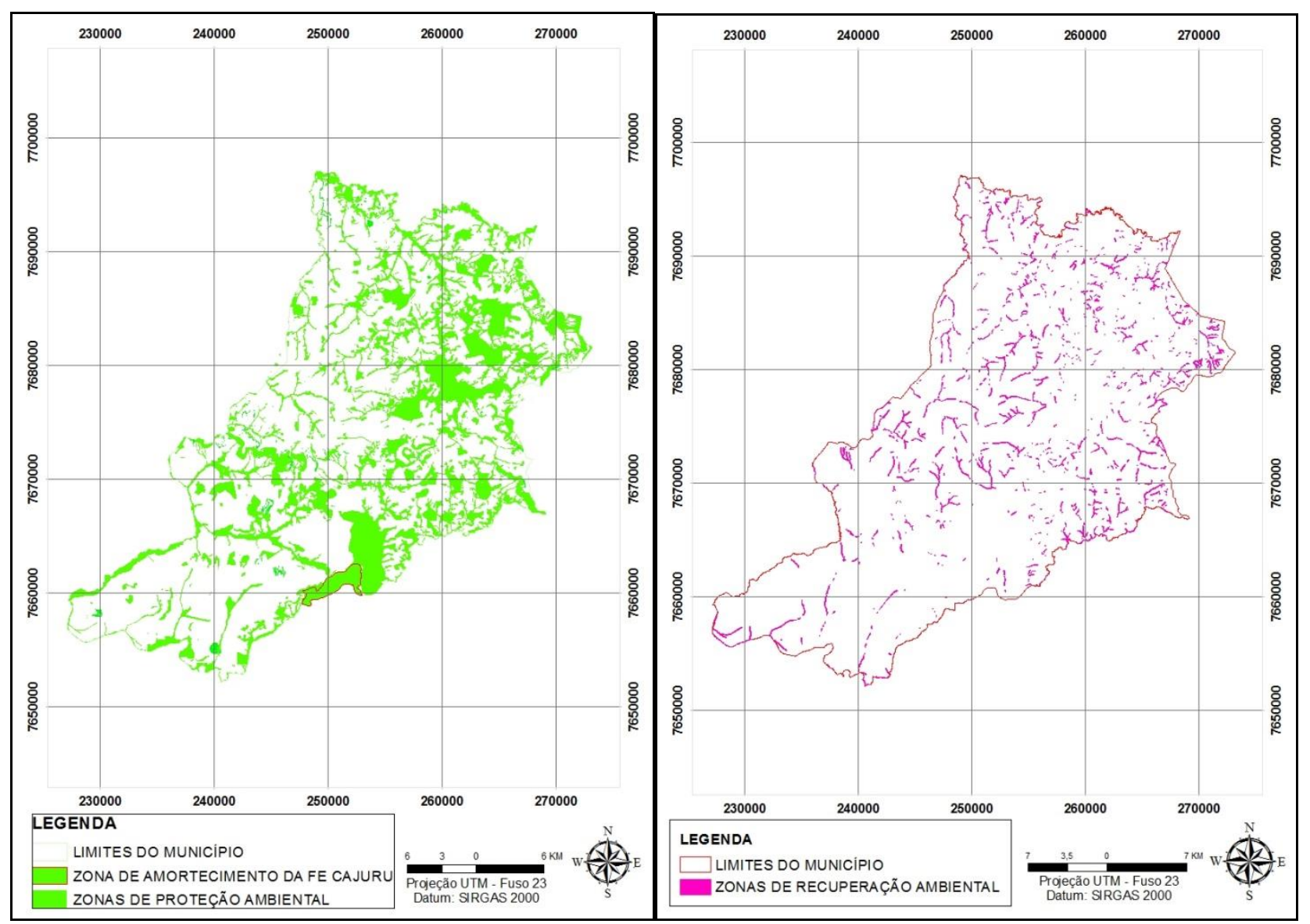

FIGURE 5. Areas of interest and environmental protection, and environmental recovery, Altinópolis - SP, Brazil.

Regarding forest fragments, the city is highly expressive compared to the other cities in the state of São Paulo. Unfortunately, some of the fragments are not under protection currently from surrounding degradation factors. In fact, edge effect, absence of linking between remnants through green corridors, isolation by fencing towards livestock and absence of firebreaks in the bordering areas with crops are observed in these areas (KRONKA, 2005).

Nonetheless, PPA recovery together with measures to lower farming impacts on forest fragments will be necessary in the coming years. These actions will be on mechanisms recently established by Normative Ruling \# 02/ 2014 and the Ordinance \# 8,234 / 2014 for the Environmental Rural Register (CAR) and the Environmental Adjustment Program (PRA) of rural properties (ELLOVITCH \& VALERA, 2013). Besides that, planning measures for establishment of ecological corridors are required to link the forest fragments and the PPAs.

OKUYAMA et al. (2012) evaluated 147 farms in eight cities of central eastern and southeastern Paraná towards the applicable Forest Code. They reported the urge to recover PPAs in $67 \%$ of the farms. For them, quantification of necessary and remaining forest cover, such as small demand for PPA readjustment (5\% of the total area given their consolidated use) enable inferring that these issues are not barriers for environmental regularization of family farming for the analyzed farms.

Despite the existence of illegally occupied PPAs, the city has an outstanding position since studies by SPAROVEK et al. (2012). These authors pointed out even if the country has $63 \%$ of its land area with native vegetation; there is still a deficit in PPAs for agroforestry activities. From the existing 100 Mha, $43 \%$ are still undocumented according to the new legislation, with the largest liability in the Northeast, followed by the Southeast, which has 10 million hectares of undocumented PPAs. Studies of the Environment Office of São Paulo state and the LUPA project 
indicated that the environmental liabilities in the state are over $50 \%$ of the 2 million hectares of existing PPAs.

Another area defined because of its peculiarity was the urban area, i.e., the space occupied by the city with its buildings, endowed with infrastructure as energy network, sewers, water supply, waste collection, schools, health centers, as well as the surrounding expansion zone (Figure 6). We also defined areas of special interest and use, which correspond to highways, railroads, rural lanes and their protective strips, besides the main rivers (Sapucaí and Pardo) (Figure 6). These areas are intended to provide in addition to the flow of farming production, every vector of urban, commercial and industrial occupation in the city.

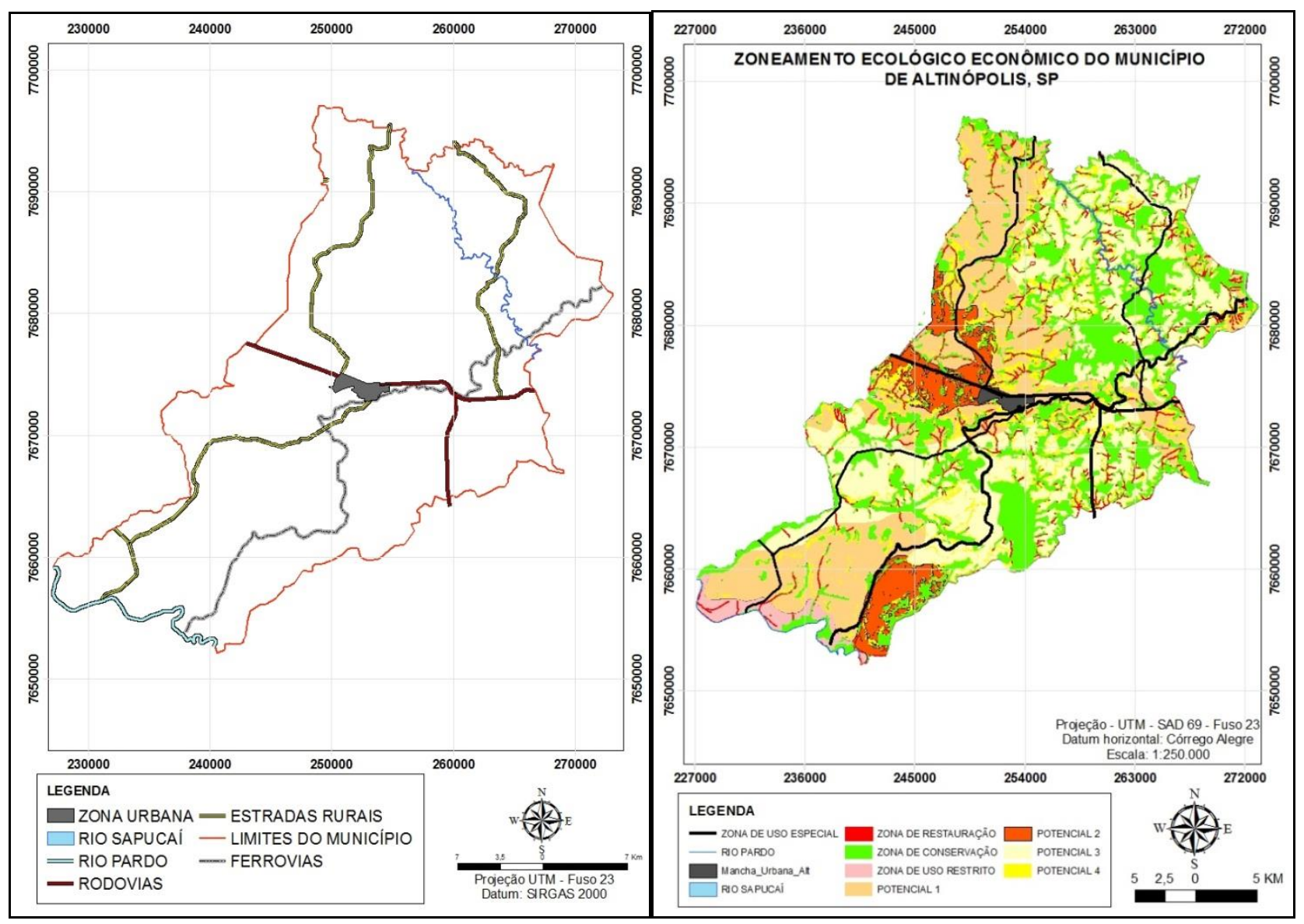

FIGURE 6. Areas of interest and environmental protection, and environmental recovery, Altinópolis - SP, Brazil.

Hence, EEZ is an essential tool for planning and sorting of land use when done from small to large-scale. However, the lack of cartographic base on an adequate scale, coupled with the absence of data updating, often enable solely approach on the planning, thus, there is need for field investigation (SILVA, 2010). Six EEZ areas were defined for Altinópolis, which were then overlapped for a better view (Figure 6).

\section{CONCLUSIONS}

A zoning model was set for the city with six areas of interest: environmental protection, environmental recovery, urban, agricultural land, special use and groundwater recharge.

The study shows that Altinópolis has important native forest fragments remaining from Cerrado and Atlantic Rainforest, occupying nearly $27.8 \%$ of the total area currently, demanding environmental preservation strategies and building green corridors to connect dispersed fragments and permanent protection areas. 
Around $23 \%$ of the existing permanent protection areas are degraded, once they are currently being filled with pastures (48\%) and sugarcane cropping (28\%) among others (24\%).

Soil types, relief, climate, altitude and easy-access geographical position bring the city into focus on the agricultural sector, wherein $70 \%$ of the total area has no restrictions for forestry and cattle farming systems.

Local geomorphology and geology boost upwelling of Guarani aquifer, wherein groundwater recharge potential is seen in $45 \%$ of the total area, which brings the need for suitable farming management in these areas.

\section{REFERENCES}

ANTUNES, P. B. Direito ambiental. 15. ed. São Paulo: Atlas, 2015. 1.422 p.

ARAUJO, C. P.; GATTAMORTA, M. A.; SILVA, S. B. da. O Zoneamento Ecológico-econômico enquanto instrumento ambiental que antecede o planejamento urbano. In: ENCONTRO

NACIONAL DA ANPUR, 14., 2011, Rio de Janeiro.

BRASIL. Ministério do meio Ambiente. Diretrizes metodológicas para o zoneamento ecológicoeconômico do Brasil. Brasília, DF, 2003.

ELlOVITCH, M. F.; VALERA, C. A. Manual do Novo Código Florestal. Belo Horizonte: Jurídico MPMG, Revista do Ministério Público do Estado de Minas Gerais, 2013.

ESRI - Environmental Systems Research Institute. Software ArcGis Desktop, License Type ArcInfo, version 10. 2011.

GARCIA, G. J.; PINTO, S. A. F.; ANTONELLO, S. L. NOBRE, M. F. O uso de geotecnologias no planejamento ambiental: o plano diretor municipal de Tambaú - SP. Revista de Engenharia. Agrícola, Jaboticabal, v.30, n.6, p. 1178-1190, 2010.

GOMES, P. M.; MONTAÑO, M. A expansão da cana-de-açúcar e o zoneamento agroambiental do setor sucroalcooleiro do estado de São Paulo. In: CONFERÊNCIA DA REDE DE LÍNGUA PORTUGUESA DE AVALIAÇÃO DE IMPACTOS, 2.; CONGRESSO BRASILEIRO DE AVALIAÇÃO DE IMPACTO, 1., 2012, São Paulo. Anais... São Paulo: ABAI, 2012. Disponível em: $\langle$ http://avaliacaodeimpacto.org.br/wpcontent/uploads/2012/10/068_zoneamento.pdf $>$. Acesso em: 14 dez. de 2012.

IPT - INSTITUTO DE PESQUISAS TECNOLÓGICAS DO ESTADO DE SÃO PAULO. Mapa geológico do estado de São Paulo. São Paulo, 1981. (IPT. Publicação 1184)

KONECNY, Gottfried. Geoinformation: Remote sensing, photogrammetry and geographic information systems. $2^{\text {nd }}$ ed. London: Taylor \& Francis Group, 2014.

KRONKA, F. J. N. (Coord.). Inventário florestal da vegetação natural do Estado de São Paulo. São Paulo: Secretaria do Meio Ambiente/Instituto Florestal, 2005. 200p.

MACHADO, P. A. L. Direito ambiental brasileiro. 21 ed. São Paulo: Malheiros Editores, 2013. $1.312 \mathrm{p}$.

MILARÉ, ÉDIS. Direito do ambiente. A gestão ambiental em foco. Doutrina. Jurisprudência. Glossário. 7. ed. São Paulo: Revista dos Tribunais, 2011.

NOVO, E. M. L. M. Sensoriamento remoto: princípios e aplicações. São Paulo: Edgard Blucher, 2010.388p.

OKUYAMA, K. K.; ROCHA, C. H.; NETO, P. H. W.; ALMEIDA, D.; RIBEIRO, D. R.

S. Adequação de propriedades rurais ao Código Florestal Brasileiro: estudo de caso no estado do Paraná. Revista de Engenharia Agrícola, Jaboticabal, v.16, n.9, p. 1015-1021, 2012. 
OLIVEIRA, G. C.; FERNANDES FILHO, E. I. Metodologia para delimitação de APPs em topo de morro segundo o novo código florestal brasileiro utilizando sistemas de informação geográfica. In: SIMPÓSIO BRASILEIRO DE SENSORIAMENTO REMOTO, 16., 2013, Foz do Iguaçu. Anais... p. 4443-4450.

OLIVEIRA, J. B. de. Solos do Estado de São Paulo: descrição das classes registradas no mapa pedológico. Campinas: IAC, 1999. 110p. (Boletim Técnico, 45).

OLIVEIRA, J.B.; MENK, J.R.; BARBIERI, J.L.; ROTTA, C.L.; TREMOCOLDI, W.

Levantamento pedológico semidetalhado do Estado de São Paulo. Quadrícula de Ribeirão Preto. Campinas: Convênio EMBRAPA/Instituto Agronômico de Campinas, 1983.

PERROTTA, M.M.; SALVADOR, E.D.; LOPES, R.C.; D’AGOSTINO, L.Z.; PERUFFO, N.; GOMES, S.D.; SACHS, L.L.B.; MEIRA, V.T.; GARCIA, M.G.M.; LACERDA FILHO, J.V. Mapa geológico do Estado de São Paulo, escala 1:750.000. Programa Geologia do Brasil - PGB, CPRM. São Paulo, 2005.

RAMALHO FILHO, A; BEEK, K. J. Sistema de avaliação da aptidão agrícola das terras. 3. ed. Rio de Janeiro: EMBRAPA-CNPS, 1995.

RODRIGUES, C. A. G.; HOTT, M. C. Dinâmica da vegetação natural no nordeste do estado de São Paulo, entre 1988 e 2003. Revista Árvore, Viçosa, MG, v. 34, n. 5, p. 881-887, 2010.

SILVA, J. C. B. Os instrumentos jurídico-econômicos conciliadores do conflito entre o desenvolvimento econômico e o meio ambiente ecologicamente equilibrado. Jus Navigandi, Teresina, v. 14, n. 2419, 14 fev. 2010. Disponível em:

<http://jus2.uol.com.br/doutrina/texto.asp?id=14347>. Acesso em: 1 mar. 2010.

SODRÉ, A. A. Novo Código Florestal Comentado Lei 12.651/2012. São Paulo: JH Mizuno, 2013.

SOUZA, M. P. As bases legais e os zoneamentos ambientais. In: SIMPÓSIO DE GEOTECNOLOGIAS NO PANTANAL, 2., 2009, Corumbá. Anais... Corumbá: EMBRAPA INFORMÁTICA AGROPECUÁRIA/INPE, 2009. p. 1089-1098.

SOUZA, C. S. de. O papel do zoneamento ambiental no planejamento municipal. 4 ed. Aracaju: PIDCC, 2013, p. 154-175.

SPAROVEK, G.; BERNDS, G.; BARRETO, A. G.; KLUG, I. L. F. The revision of the Brazilian Forest Act: increased deforestation or a historic step towards balancing agricultural development and nature conservation? Environmental Science \& Policy, v. 16, p. 65-72, 2012.

TORRES, A. J. Projeto LUPA 2007/2008: Censo Agropecuário do Estado de São Paulo. São Paulo: IEA/CATI/SAA, 2008. Disponível em: <http:www.cati.sp.gov.br/projetolupa>. Acesso em: 18 abr. 2011.

ZORZETTO, R. O verde clandestino. Pesquisa Fapesp, São Paulo, n.170, 2010. Disponível em: <http://revistapesquisa.fapesp.br/?art=4102\&bd=1\&pg=1\&lg=>. Acesso em: 5 fev. 2011. 